\title{
Kronik Hepatit B Enfeksiyonu Olan Hastalarda HBsAg ve $H B e A g$ Değerlerinin HBV DNA ve Alanin Aminotransferaz Düzeyleri ile Karșılaștırılması
}

\author{
Comparison of HBsAg and HBeAg Levels with HBV DNA and ALT Levels in Patients with \\ Chronic Hepatitis B Infections
}

\author{
İmran SAĞLIK1, Derya MUTLU1, Gözde ÖNGÜT1, Hülya İren GÜVENÇ1, Halide AKBAŞ2, \\ Dilara ÖĞ̈NÇ1, Dilek ÇOLAK1 \\ ${ }^{1}$ Akdeniz Üniversitesi Tıp Fakültesi, Tıbbi Mikrobiyoloji Anabilim Dalı, Antalya, Türkiye \\ ${ }^{2}$ Akdeniz Üniversitesi Tip Fakültesi, Tıbbi Biyokimya Anabilim Dalı, Antalya, Türkiye
}

\section{ÖZET}

Amaç: Kronik hepatit B (KHB) enfeksiyonunun tanısında ve takibinde serolojik belirteçler, viral yük ve alanin aminotransferaz (ALT) düzeyinin ölçümü sıkııla kullanılan yöntemlerdir. Son yıllarda ise, HBV DNA ve ALT düzeylerinin $\mathrm{HBs} A g$ ve $\mathrm{HBeAg}$ düzeyleri ile ilişkili olduğu gündeme gelmiştir. Bu çalışmanın amacı, KHB hastalarında, $\mathrm{HBsAg}$ ve $\mathrm{HBeAg}$ düzeylerinin $\mathrm{HBV}$ DNA ve ALT düzeyleri ile karşılaştırılmasıdır.

Gereç ve Yöntemler: Akdeniz Üniversitesi Hastanesi Mikrobiyoloji Laboratuvarı'na $\mathrm{HBsAg}$, $\mathrm{HBeAg}$ ve $\mathrm{HBV}$ DNA düzeylerinin tespiti için gönderilen 356 hastaya ait 402 serum örneği calıșmaya dahil edildi. Örneklerin tamamı HbsAg pozitifti. HBsAg ve HBeAg değerleri Modular Analitics E170 (Roche Diagnostics, Almanya) sisteminde, ALT değerleri Roche Hitachi Cobas 8000 Modular Analyzer'da (Roche Diagnostics, Almanya) ölçüldü. HBV DNA düzeyleri, Cobas TaqMan testi (Roche Diagnostics, Almanya) kullanılarak ölçüldü.

Bulgular: Sadece HBsAg ölçüm düzeyi 400 s/co'a kadar olan 51 serum örneğ değerlendirildiğinde, HBsAg ile HBV DNA düzeyi arasında pozitif korelasyon olduğu görüldü $(p<0,001)$. Tüm örnekler değerlendirildiğinde $\mathrm{HBeAg} s / \mathrm{co}$ düzeyleri ve HBV DNA düzeyleri arasında pozitif korelasyon görüldü ( $p<0,001)$. HbeAg pozitif ( $n=107$ ) hastalarda HBV DNA düzeyleri ve ALT düzeyleri HBeAg negatif $(n=295)$ hastalardan anlamlı derecede yüksekti $(p<0,001)$. ALT düzey normalden yüksek olan ( $n=112$ ) hastalarda HBV DNA ve HBeAg s/co düzeyleri ALT düzeyi normal olanlara göre yüksek olarak bulundu $(p<0,001)$.

Sonuç: KHB hastalarında, HBeAg ve HBsAg ölçüm değerleri ile HBV DNA düzeyleri arasında pozitif korelasyon bulunmuștur. Ancak HBsAg ölçümü için serum örnekleri uygun şekilde dilüsyon yapılarak çalışılmalıdır. HBeAg'nin s/ co ölçüm değeri, ALT ve/veya HBV DNA düzeyleri için yol gösterici olabilir (Viral Hepatit Dergisi 2013; 19(3): 119-22)

Anahtar Kelimeler: Kronik hepatit B, HBsAg, HBeAg, HBV DNA

\section{ABSTRACT}

Objective: Serologic markers, viral load determinations and serum ALT values are commonly used for diagnosis and treatment of chronic Hepatitis B virus infections. In recent years, $\mathrm{HBs} A g$ and $\mathrm{HBeAg}$ values has been raised to be associated with HBV DNA and ALT levels. The aim of this study is compare the HBsAg and HBeAg values with HBV DNA and ALT values.

Materials and Methods: This study included 402 serum and plasma samples of 356 patients with chronic hepatitis $\mathrm{B}$ that were asked for determination of $\mathrm{HBsAg}$ HBeAg and HBV DNA levels to Microbiology Laboratory of Akdeniz University Medical Faculty Hospital. HBsAg and HBeAg levels were measured by using the Modular Analitics E170 system (Roche Diagnostics, Germany). All samples were positive for HBsAg. ALT levels were detected by using the Roche Hitachi Cobas 8000 Modular Analyzer system (Roche Diagnostics, Germany). HBV DNA levels were determined by using Cobas Taqman assay (Roche Diagnostics, Germany).

Results: When 51 of the serum samples which had HBsAg values up to $400 \mathrm{~s} / \mathrm{co}$ were evaluated, there have been a positive correlation with HBsAg and HBV DNA values $(p<0.001)$. In all of the samples, there have been a positive correlation with HBeAg $s / c o$ values and HBV DNA levels $(p<0.001)$. HBV DNA levels and serum ALT levels were higher in patients with $\mathrm{HBeAg}$ positivity $(\mathrm{n}=107)$, when compared with patients who were negative for $\mathrm{HBeAg}(\mathrm{n}=295)(\mathrm{p}<0.001)$. HBV DNA and $\mathrm{HBeAg}$ $s / c o$ values were higher in patients with high serum ALT levels $(n=112)$, when compared with patients who had normal ALT values $(\mathrm{p}<0.001)$.

Conclusion: In patients with chronic Hepatitis B infection, $\mathrm{HBeAg}$ and $\mathrm{HBsAg}$ measurement values were positively correlated with HBV DNA levels. However, serum HBsAg levels must be measured with properly diluted samples. $\mathrm{HBeAg} \mathrm{s} / \mathrm{co}$ values, may be indicators for the existence of high ALT and HBV DNA values. (Viral Hepatitis Journal 2013; 19(3): 119-22)

Key words: Chronic hepatitis B, HBsAg, HBeAg, HBV DNA

Yazıșma Adresi/Address for Correspondence: Dr. Dilek Çolak, Akdeniz Üniversitesi Tıp Fakültesi Tıbbi Mikrobiyoloji Anabilim Dalı, Antalya, Türkiye Tel.: +90 2422496911 E-mail: dcolak@akdeniz.edu.tr Geliş tarihi/Received: 08.07.2013 Kabul tarihi/Accepted: 08.10.2013 (c) Viral Hepatit Dergisi, Galenos Yayınevi tarafindan basılmıștır. /Viral Hepatitis Journal, published by Galenos Publishing. 


\section{Giriş}

Hepatit B virüsü (HBV) tüm dünyada kronik karaciğer hastalığına yol açan en önemli patojenlerden birisidir. Hepatit B enfeksiyonu tanısı genellikle hasta serumunda viral antijenlerin ( $\mathrm{HbsAg}, \mathrm{HbeAg})$ ve/veya antikorların (Anti Hbs, Anti Hbe, Anti Hbc lgM-lgG) değerlendirilmesiyle konur. HBsAg, HBV enfeksiyonunu göstermek için en sık kullanılan temel belirteçtir (1). HbsAg'nin altı aydan uzun süre ile pozitif kalması, hepatit B enfeksiyonunun kronikleştiğinin göstergesidir.

Kronik hepatit $B(K H B)$ hastalarında klinik seyrin izlenmesinde HBsAg, HBeAg serokonversiyonu, HBV DNA ve alanin aminotransferaz (ALT) düzeylerinin takibi yol gösterici olmaktadır (2). HBsAg, HBeAg ve HBV DNA farklı, fakat birbirini tamamlayıCI parametrelerdir. HBV DNA ve $\mathrm{HBeAg}$ viral replikasyonun göstergesidir. HBsAg kompleks bir mekanizma ile üretilir ve serum HBsAg düzeyi ile karaciğerdeki cccDNA'nın (covelently closed circular DNA) transkripsiyonel aktivitesi uyumlu bulunmuştur. cccDNA'nın tespiti için invazif yöntemler gerekir (2-4). Son yıllarda serolojik belirteçlerin tespitinde kullanılan otomatize ölçüm sistemlerinin gelişmesi, HBsAg ve HBeAg düzeylerinin hastalığın seyrinde belirteç olarak kullanılabileceğini gündeme getirmiştir. Ticari olarak kantitatif HBsAg ölçümü yapan iki farklı kit mevcuttur. Her iki kit de kantitasyon için serum örneklerine dilüsyon önermekte ve $\mathrm{IU} / \mathrm{ml}$ olarak sonuç vermekte olup, kitlerin sonuçları birbirleriyle uyumlu bulunmuştur (5). Tanı ve tedavi takibinde daha ucuz yöntem arayışları hepatit B serolojik belirteçleri ile hastalık seyrini ve/veya HBV DNA düzeylerini karşılaştıran çeşitli çalışmalar yapıımasına yol açmıştır (4).

Bu çalışmanın amacı, KHB hastalarında elektrokemiluminesan yöntemle ölçülen yarı kantitatif $\mathrm{HBsAg}, \mathrm{HBeAg}$ ölçüm değerlerinin HBV DNA ve ALT düzeyleri ile karşılaştırılmasıdır.

\section{Gereç ve Yöntem}

Akdeniz Üniversitesi Hastanesi Merkez Laboratuvarı Mikrobiyoloji Bölümü'ne 2010 yılı içerisinde KHB tanısı ile izlenen 356 hastaya ait, HBsAg, HBeAg, HBV DNA ve ALT düzeylerinin eş zamanlı olarak çalışılması için gönderilen, 402 serum örneği çalışmaya dahil edildi. Hastaların yaş ortalaması 35 16 ( aralık 2-86), $103(\% 28,93)$ kadın, $253(\% 71,06)$ erkek idi. Hasta serumlarında $\mathrm{HBsAg}$ ve $\mathrm{HBeAg}$ değerleri HBsAg II kiti ve HbeAg kiti ile Modular Analytics E170 (Roche Diagnostics, Mannheim, Almanya) otomatize sisteminde elektrokemiluminesan yöntemle s/co (sample/cut

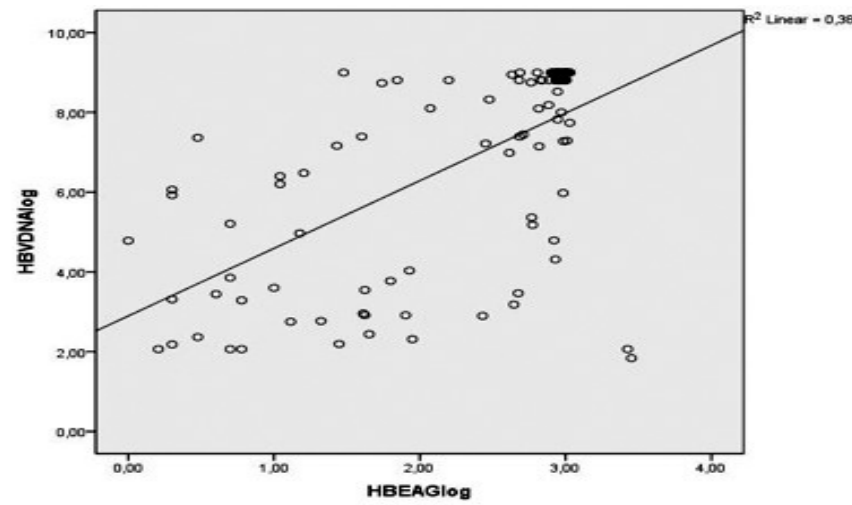

Şekil 1. Tüm örneklerde HBV DNA düzeyleri ve $\mathrm{HBeAg} \mathrm{s/co}$ düzeyleri arasında pozitif korelasyon görüldü $(r=0,657, p<0,001)$. off=örnek/eşik değer) sinyali olarak ölçüldü. Serum ALT düzeyleri, Cobas 8000 otoanalizöründe (Roche Diagnostics, Mannheim, Almanya) üretici firma önerilerine göre ölçüldü (kadınlarda $33 \mathrm{U} / \mathrm{L}$, erkeklerde $41 \mathrm{U} / \mathrm{L}$ üzerindeki değerler üretici firmanın önerilerine göre yüksek kabul edildi). HCV, HDV ve HIV antikoru pozitif hastalara ait örnekler çalışmaya alınmadı. Hastaların tedavi alıp almadığı ve HBV genotip farklııkları dikkate alınmadı. HBV DNA düzeyleri gerçek zamanlı kantitatif PCR (polimeraz zincir reaksiyonu) yöntemi ile (CAP/CTM, Roche Diagnositcs, Mannheim, Almanya) hastalara ait eş zamanlı plazma örneklerinden ölçüldü.

Istatistiksel değerlendirme için SPSS 16.0 programında, MannWhitney $U$ testi ve Pearson korelasyon analizinden yararlanıldı. $p$ $<0,05$ olan değerler anlamlı kabul edildi.

\section{Bulgular}

Çalışmaya alınan HBsAg pozitif 402 hasta örneğinin 107'si HBeAg pozitif, 295'i HBeAg negatif, 370'i HBV DNA pozitif, 32'si HBV DNA negatif, 112'sinin ALT düzeyi normalden yüksek, 290'ının ALT düzeyi normal değerlerde bulundu. HbeAg pozitif ( $n=107)$ hastalarda HBV DNA pozitifliği $(\% 98,1) \mathrm{HBeAg}$ negatif hastalardan yüksekti $(\% 89,8)$. HBeAg ve HBV DNA pozitif örneklerin \%55,2'sinde, HBeAg ve HBV DNA negatif hastaların \%10'unda ALT düzeyleri normalden yüksek bulundu $(p<0,001)$ (Tablo 1).

Serolojik parametreler için saptanan ortalama değerler ( \pm standart sapma, en düşük-en yüksek): HbsAg 3065 s/co ( \pm 1956 , 2-6378), HBeAg $149 \mathrm{~s} / \mathrm{co}$ ( $\pm 327,0-2836)$, HBV DNA 9.0×106 $\mathrm{IU} / \mathrm{ml}$ $\left( \pm 3,5 \times 10^{7}, 0-1,7 \times 10^{8}\right)$ olarak hesaplandı.

Tüm örnekler değerlendirildiğinde de HBV DNA düzeyleri ile $\mathrm{HBeAg}$ s/co düzeyleri arasında pozitif korelasyon olduğu görüldü $(r=0,657, p<0,001)$ (Şekil 1). Sadece HBsAg düzeyi 400 s/co'a kadar olan örnekler $(n=51)$ değerlendirildiğinde HBsAg ile HBV DNA düzeyi arasında ve $\mathrm{HBeAg}$ düzeyi arasında pozitif korelasyon olduğu görüldü (sırasıyla $r=0,579, p<0,001 ; r=0,615, p<0,001$ ).

Tüm örnekler değerlendirildiğinde ise $\mathrm{HBsAg}$ ve HBV DNA düzeyleri arasında ve $\mathrm{HBsAg}$ düzeyi ile $\mathrm{HBeAg}$ arasında da negatif korelasyon olduğu görüldü (sırasıyla $r=-432, p<0,001$; $r=-454$, $p<0,001)$. HbeAg pozitif $(n=107)$ hastalarda yüksek HBV DNA

\begin{tabular}{|c|c|c|c|c|}
\hline \multirow{2}{*}{\multicolumn{2}{|c|}{ Özellik }} & \multicolumn{2}{|c|}{ ALT } & \multirow{3}{*}{$\begin{array}{c}\text { Toplam } \\
105\end{array}$} \\
\hline & & \multirow{2}{*}{$\begin{array}{c}\text { Normal } \\
47\end{array}$} & \multirow{2}{*}{$\begin{array}{c}\text { Yüksek } \\
58\end{array}$} & \\
\hline \multirow[b]{2}{*}{ HBeAg poz } & HBV DNA poz & & & \\
\hline & HBV DNA neg & 2 & 0 & 2 \\
\hline \multirow{3}{*}{ HBeAg neg } & HBV DNA poz & 214 & 51 & 265 \\
\hline & HBV DNA neg & 27 & 3 & 30 \\
\hline & Toplam & 290 & 112 & 402 \\
\hline
\end{tabular}

\begin{tabular}{|c|l|l|l|l|}
\hline \multicolumn{2}{|c|}{ Tablo 2. HBeAg ve ALT düzeylerinin karşılaştırılması } & \multicolumn{2}{|c|}{ ALT } \\
\cline { 2 - 4 } & $\begin{array}{c}\text { Normal } \\
n=290(\% 72,1)\end{array}$ & $\begin{array}{c}\text { Yüksek } \\
n=112(\% 27,9)\end{array}$ & p değeri \\
\hline \multirow{2}{*}{ HBeAg } & Neg (n=295) & $241(\% 81,7)$ & $54(\% 18,3)$ & $p<0,001$ \\
\cline { 2 - 4 } & Poz (n=107) & $49(\% 45,8)$ & $58(\% 54,2)$ & $p<0,001$ \\
\hline & $\begin{array}{l}\text { HBeAg s/co } \\
\text { ortalama değeri }\end{array}$ & $89,94( \pm 19$ SD) & $302,49( \pm 37$ SD) & $p<0,001$ \\
\hline
\end{tabular}


düzeylerine ve normalden yüksek $A L T$ düzeylerine rastlanma sıklığı HBeAg negatif $(n=295)$ hastalardan anlamlı derecede yüksekti. $\mathrm{HBeAg}$ pozitif hastaların \%54,2'sinde, $\mathrm{HBeAg}$ negatif hastaların \%18,3'ünde ALT düzeyleri normalden yüksekti. ALT düzeyi normalden yüksek olan $(n=112)$ hastalarda HBV DNA düzeyleri ve $\mathrm{HBeAg}$ s/co düzeyleri, $\mathrm{ALT}$ düzeyi normal olanlara göre yüksek olarak bulundu ( $p<0,001)$ (Tablo 2). HBsAg düzeyleri ile ALT düzeyleri arasında ilişki saptanmadı.

\section{Tartıșma}

$\mathrm{Bu}$ çalışmada KHB enfeksiyonu olan hastalarda HBsAg, HBeAg, HBV DNA ve ALT düzeyleri karşılaştırılmıştır. HBV DNA düzeyi ile HbeAg s/co düzeyi arasında anlamlı pozitif korelasyon saptanmıştır. Li ve ark. çalışmalarında $228 \mathrm{HBeAg}$ pozitif hastada HBV DNA düzeyi ile $\mathrm{HBeAg}$ arasında pozitif korelasyon tespit etmişlerdir (6). HBsAg'nin aksine, HbeAg düzeyini kantite eden ticari bir kit yoktur. Ancak referans olarak bir standart serum kullanılarak HBeAg'nin $\mathrm{U} / \mathrm{mL}$ olarak kantite edildiği çalışmalar yapılmış ve bu çalışmalarda HBeAg ile HBV DNA ölçümleri arasında pozitif korelasyon saptanmıștır (7-10). Wursthorn ve ark. 2011 ylında HBeAg'nin kantitasyonu ile ilgili çalışmalarında bir dilüsyon protokolü önermişlerdir (11). Bunlarla birlikte HbeAg s/co ölçüm değerleri ile HBV DNA arasında pozitif korelasyon saptayan çalışmalar da yayınlanmıștır $(12,13)$. Ulaşılabildiği kadarı ile, daha önceki çalışmalarda bu iki parametre arasında anlamlı korelasyon saptamayan sadece bir çalışmaya rastladık (14).

HBV DNA ile HBsAg ilişkisini değerlendiren çok sayıda çalışma yapılmış ve farklı sonuçlara ulaşıımıştır. Bu çalışmaların birçoğunda HBsAg ve HBV DNA düzeyleri arasında pozitif korelasyon saptanmıştır $(4,8,15-18)$. Bununla birlikte herhangi bir ilişkinin saptanmadığı $(6,19,20)$ veya negatif ilişkinin saptandığı çalışmalar da (14) yayınlanmıştır. Biz çalışmamızda sadece HBsAg s/co değeri 400'e kadar olan hastalarda HBV DNA ile HBsAg arasında pozitif korelasyon saptarken tüm hastaları değerlendirdiğimizde negatif korelasyon olduğunu gördük. Yüksek konsantrasyonda antijen içeren serum örneklerinde yüksek doz çengel (hook) etkisinden dolayı antijen miktarının olduğundan daha az ölçülebildiği bilinmektedir $(11,21)$. HBsAg kantitasyonu için Roche ve Abbot firmalarına ait iki ticari kit mevcut olup, her ikisi de serum örneklerini dilüsyon ile çalışmayı önermektedir. Biz çalışmamızda kalitatif olarak ölçüm yapsa da belirli oranda antijen miktarını yansıtacağını düşündüğümüz HBsAg II kiti ile çalıştık ancak hiçbir örnek için dilüsyon yapmadık. Bu nedenle $\mathrm{HBsAg}$ s/co değeri yüksek olan örneklerde antijen miktarının doğru olarak kantite edilemediğini ve HBV DNA ile negatif korelasyon varmış gibi yanıltıcı bir sonucun ortaya çıktığını düşünmekteyiz. Çalışmamızda saptanan $\mathrm{HBeAg}$ düzeyleri ortalama olarak $\mathrm{HBsAg}$ düzeylerine göre daha düşük olduğundan (HbsAg 3065 [ $\pm 1956,2-6378]$ s/co, HBeAg 149 [ \pm $327,0-2836$ ] s/co), dilüsyon yapılmasa da HbeAg düzeylerinin daha doğru kantite edilebildiğini, bu durumda da beklendiği gibi HBV DNA ile HBeAg arasında pozitif korelasyon görüldüğünü düşünmekteyiz. Bu sonuçlar dikkate alındığında yüksek konsantrasyonda antijen içeren serum örneklerinde, antijenin kantitasyonu yapılırken dilüsyon oranlarının çok iyi hesaplanması gerektiği görülmektedir. Semikantitatif ölçüm yapan HBsAg II ticari kitinin (Roche Diagnostics) kantitatif HBsAg ölçümü için kullanılması durumunda uygun olabilecek dilüsyon algoritmalarını belirlemek için çeşitli çalışmalar yapılmıştır $(22,23)$. Bu çalışmalarda serum örneklerinin ilk olarak 1/400 oranında dilüsyon yapılarak çalışıması, gerekli görülürse ileri dilüsyonlar yapılması önerilmiştir. Bu tür literatür bilgileri dikkate alınarak yapılan çalışmaların daha doğru sonuçlar vereceğini düşünmekteyiz. HBsAg ve HBV DNA arasında pozitif korelasyon saptamayan çalışmalarda bunun sebebinin hastalığın klinik fazı olabileceği gibi (24), çalışmamıza benzer şekilde serum örneklerinin dilüsyon yapılmadan çalışılmış olmasına bağıı olabileceği de $(20,25)$ unutulmamalıdır.

$\mathrm{Bu}$ çalışmada ALT belirteci normal ve normalden yüksek değerler olarak iki gruba ayrıldı ve yüksek ALT düzeyi ile HBsAg düzeyi arasında pozitif bir ilişki olmadığı görüldü. Nguyen ve ark. (24), Manesis ve ark. (18), Brunetto ve ark. (26) yayınladıkları çalışmalarında ALT düzeyi ile HBsAg arasında korelasyon saptamamışlardır.

Çalışmalarda $\mathrm{HBeAg}$ pozitif hastaların negatiflere oranla daha yüksek replikasyon düzeyine sahip oldukları belirtilmiştir $(27,28)$. Togo ve ark. (29) çalışmalarında, bizim çalışmamıza benzer şekilde $\mathrm{HBeAg}$ pozitif hastalarda ALT düzeyinin ve HBV DNA düzeyinin daha yüksek olduğunu belirtmişlerdir. Bu çalışmada HBeAg pozitif hastaların \%54,2'sinde ALT düzeyleri normalden yüksekken bu oran $\mathrm{HBeAg}$ negatif olanlarda \%18,3'tü. ALT düzeyi yüksek olan hastaların $\mathrm{HBeAg}$ ve HBV DNA ortalama değerleri ALT düzeyleri normal olanlardan anlamlı olarak daha yüksekti $(p<0,001)$.

HBV DNA ve ALT düzeyleri ile antiviral tedavi yanıtı izlenirken, genellikle hastalardan ardışık olarak alınan serum örneklerinden ölçümler yapılarak tedavi süreci yönlendirilir. Bir çok çalışmada HBsAg ve $\mathrm{HBeAg}$ değerleri benzer şekilde ölçülerek tedavinin izlenmesinde kullanılabilirlikleri değerlendirilmiştir $(6,7,9,10,12,13,17,18)$. Ancak bu çalışmada hastalardan eş zamanlı alınan serum örneklerinde HBsAg, HBeAg ölçüm değerleri HBV DNA ve ALT düzeyleri ile karşılaştırılmış ve sonuçların araştırıcılar için yol gösterici olacağı düşünülmüştür. Ancak tedavi yanıtının değerlendirilmesinde ardışık olarak alınan örneklerden yapılan ölçümlerin değerlendirilmesi daha uygun olacaktır. Ülkemizde son yıllarda bu alanda yapılmış çalışmaya rastlanmamıştır.

Sonuç olarak, HBeAg ölçüm değerleri ile viral DNA düzeyleri arasında pozitif korelasyon saptanmıștır. Tüm serum örneklerinde HBsAg s/co değerleriyle HBV DNA ölçüm değerleri arasında pozitif korelasyon görülmemiştir, ancak HBsAg düzeyinin ölçüm değerleri 400 s/co'a kadar olan örnekler değerlendirildiğinde, HBsAg ölçüm değerleri ile viral DNA düzeyi arasında pozitif korelasyon olduğu görülmüştür. HBsAg ve HBeAg kantitatif olarak ölçüldüğünde HBV DNA'nın yerini tutmamakla birlikte yol gösterici olabilirler. Benzer şekilde yüksek HBeAg ölçüm değerleri, yüksek ALT değerleri için yol gösterici olabilir.

\section{Çıkar Çatışması: Bildirilmemiştir.}

\section{Kaynaklar}

1. Dufour DR. Hepatitis B surface antigen (HBsAg) assays--are they good enough for their current uses? Clin Chem. 2006; 5: $1457-9$

2. Valsamakis A. Molecular testing in the diagnosis and management of chronic hepatitis B. Clin Microbiol Rev. 2007; 20: 426-39.

3. Brunetto MR. A new role for an old marker, HBsAg. J Hepatol. 2010; 52(4): 475-7

4. Lee JM, Ahn SH. Quantification of HBsAg: basic virology for clinical practice. World J Gastroenterol. 2011; 17: 283-9.

5. Sonneveld MJ, Rijckborst V, Boucher CA, Zwang L, Beersma $M F$, Hansen BE, Janssen HL. A comparison of two assays for quantification of Hepatitis B surface Antigen in patients with chronic hepatitis B. Clin Virol. 2011; 51: 175-8. 
6. Li MH, Xie $Y$, Qiu GH, Lu Y, Zhao $H$, Yang $M$, et al. The relationship of serum $\mathrm{HBsAg}, \mathrm{HBeAg}$ concentration and HBVDNA load in chronic hepatitis B during IFN treatment. Zhonghua Shi Yan He Lin Chuang Bing Du Xue Za Zhi. 2011; 25: 26-8.

7. Lee JM, Ahn SH, Kim HS, Park H, Chang HY, Kim do Y et al. Quantitative hepatitis B surface antigen and hepatitis B e antigen titers in prediction of treatment response to entecavir. Hepatology. 2011; 53

8. Thompson AJ, Nguyen T, Iser D, Ayres A, Jackson K, Littlejohn $M$ et al. Serum hepatitis B surface antigen and hepatitis $B$ e antigen titers: disease phase influences correlation with viral load and intrahepatic hepatitis B virus markers. Hepatology. 2010; 51: 1933-44.

9. Heijtink RA, Kruining J, Honkoop P, Kuhns MC, Hop WC, Osterhaus AD, Schalm SW. Serum HBeAg quantitation during antiviral therapy for chronic hepatitis B. J Med Virol.1997; 53: 282-7.

10. Silva LC, Nova ML, Ono-Nita SK, Pinho JR, Sitnik R, Santos VA, Carrilho FJ. Simultaneous quantitation of serum HBV DNA and $\mathrm{HBeAg}$ can distinguish between slow and fast viral responses to antiviral therapy in patients with chronic hepatitis B. Rev Inst Med Trop Sao Paulo. 2009; 51: 261-8.

11. Wursthorn K, Zacher BJ, Jaroszewicz J, Darnedde M, Manns $\mathrm{M}$, Wedemeyer $\mathrm{H}$. Development of a protocol for the quantitative determination of $\mathrm{HBeAg}$ using the Elecsys $₫$ HBeAg immunoassay J Viral Hepat. 2011; 18: 179-83.

12. Park NH, Shin JW, Park JH, Bang SJ, Kim DH, Joo KR, Kim DH. Monitoring of $\mathrm{HBeAg}$ levels may help to predict the outcomes of lamivudine therapy for $\mathrm{HBeAg}$ positive chronic hepatitis B. J Viral Hepat. 2005; 12: 216-21.

13. Dou YL, Cheng XQ, Li YZ, Han JH, Ni AP, Park NH et al. Monitoring of HBeAg levels may help to predict the outcomes of lamivudine therapy for $\mathrm{HBeAg}$ positive chronic hepatitis B. J Viral Hepat. 2005; 12: 216-21.

14. Wiegand J, Wedemeyer $H$, Finger A, Heidrich B, Rosenau $\mathrm{J}$, Michel $\mathrm{G}$ et al. A decline in hepatitis B virus surface antigen (hbsag) predicts clearance, but does not correlate with quantitative hbeag or HBV DNA levels. Antivir Ther. 2008; 13: 547-54.

15. Deguchi M, Yamashita N, Kagita M, Asari S, Iwatani Y, Tsuchida $T$ et al. Quantitation of hepatitis B surface antigen by an automated chemiluminescent microparticle immunoassay. J Virol Methods. 2004; 115: 217-22.

16. Chen $\mathrm{CH}$, Lee $\mathrm{CM}$, Wang JH, Tung HD, Hung $\mathrm{CH}$, Lu SN Correlation of quantitative assay of hepatitis B surface antigen and HBV DNA levels in asymptomatic hepatitis B virus carriers. Eur J Gastroenterol Hepatol. 2004

17. Fung J, Lai CL, Young J, Wong DK, Yuen J, Seto WK, Yuen MF. Quantitative hepatitis B surface antigen levels in patients with chronic hepatitis B after 2 years of entecavir treatment. Am J Gastroenterol. 2011; 106: 1766-73.
18. Manesis EK, Papatheodoridis GV, Tiniakos DG, Hadziyannis ES Agelopoulou OP, Syminelaki T, et al. Hepatitis B surface antigen: relation to hepatitis $B$ replication parameters in $\mathrm{HBeAg}$-negative chronic hepatitis B. J Hepatol. 2011; 55: 61-8.

19. Kuhns MC, Kleinman SH, McNamara AL, Rawal B, Glynn S, Busch MP. Lack of correlation between HBsAg and HBV DNA levels in blood donors who test positive for HBsAgand antiHBc: implications for future HBV screening policy. Transfusion. 2004; 44: 1332-9.

20. Ganji A, Esmaeilzadeh A, Ghafarzadegan K, Helalat $H$, Rafatpanah H, Mokhtarifar A. Correlation between HBsAg quantitative assay results and HBV DNA levels in chronic HBV. Hepat Mon. 2011; 11: 342-5.

21. Zacher BJ, Moriconi F, Bowden S, Hammond R, Louisirirotchanakul S, Phisalprapa $P$ et al. Multicenter evaluation of the Elecsys hepatitis B surface antigen quantitative assay. Clin Vaccine Immunol. 2011; 18: 1943-50

22. Bonino F, Ofenloch B, Melchior W, Upmeier B, Rößler D, van der Helm W. Quantitative assessment of serum HBsAg levels using the Elecsys ${ }^{\circledR}$ HBsAg II screening assay: results of a feasibility study. In: 59th annual meeting of the American association for the study of liver diseases 2008: P934.

23. Wursthorn K, Jaroszewicz J, Zacher BJ, Darnedde M, Raupach R, Mederacke I et al. Correlation between the Elecsys HBsAg II assay and the Architect assay for the quantification of hepatitis B surface antigen (HBsAg) in the serum. J Clin Virol. 2011; 50: 292-6.

24. Nguyen T, Thompson AJ, Bowden S, Croagh C, Bell S, Desmond $P V$, et al. Hepatitis B surface antigen levels duringthe natural history of chronic hepatitis B:a perspective on Asi.J Hepatol. 2010; 52: 508-13.

25. Sayan M, Mutlu B, Erdoğan S, Meriç M, Willke A. Can HBsAg levels guide to differentiate inactive $\mathrm{HBsAg}$ carriers from HBeAg negative chronic B hepatitis?. Mikrobiyol Bul. 2007; 41: 87-93.

26. Brunetto MR, Moriconi F, Bonino F, Lau GK, Farci P, Yurdaydin C et al. Hepatitis B virus surface antigen levels: a guide to sustained response to peginterferon alfa-2a in $\mathrm{HBeAg}$-negative chronic hepatitis B. Hepatology. 2009; 49: 1141-50.

27. Yalçın K, Değertekin H, Alp MN, Tekeş S, Yıldız F, Kılınç N et al. Tedavi Edilmemiş Kronik Hepatit B'li Hastalarda Serum HBV DNA Düzeylerinin HBeAg/Anti-HBe Durumu, Karaciğer Histolojisi, ALT Düzeyleri ve Yaşla Korelasyonu. 2003; 14: 3.

28. Altındiş M. Hepatit B Virüs (HBV) Serolojik Belirleyicileri ile HBV DNA'nın varlığının karşılaştııılması. Infeksiyon Dergisi. 2002; 16 $: 141-5$.

29. Togo S, Arai M, Tawada A, Chiba T, Kanda T, Fujiwara K, et al. Clinical importance of serum hepatitis B surface antigen levels in chronic hepatitis B. J Viral Hepat. 2011; 18: 508-15. 